\title{
DAMPAK PERUBAHAN PENGGUNAAN LAHAN PERTANIAN TERHADAP SOSIAL EKONOMI PETANI SEKITAR LOKASI PERTAMBANGAN BANYU URIP KECAMATAN GAYAM KABUPATEN BOJONEGORO
}

\author{
Agricultural Land Use Changes Impacts on the Farmers' Socio- \\ Economic Condition around the Banyu Urip Petroleum Mining \\ Project in District Gayam, Kabupaten Bojonegoro
}

Aziz Bahtiar Rifa'i dan Fadjar Hari Mardiansjah²

Diterima: 8 Maret 2017

Disetujui: 13 Februari 2018

\begin{abstract}
Abstrak: Penelitian ini mengkaji dampak perubahan penggunaan lahan pertanian menjadi area pertambangan terhadap sosial ekonomi petani di sekitar area pertambangan minyak bumi Kecamatan Gayam Kabupaten Bojonegoro. Metode yang digunakan adalah mix method yaitu menggunakan pendekatan kuantitatif dan kualitatif. Pendekatan kuantitatif digunakan untuk mengetahui dampak perubahan penggunaan lahan pertanian pada aspek sosial ekonomi dengan responden petani yang didukung dengan metode skoring untuk mengetahui kondisi kerentanan sosial ekonomi petani. Sedangkan pendekatan kualitatif dilakukan melalui wawancara mendalam pada narasumber yang telah ditentukan. Hasil penelitian menunjukkan bahwa keberadaan industri pertambangan belum berdampak positif terhadap sosial ekonomi petani. Perubahan lahan pertanian sebesar 700 ha, menyebabkan produksi pertanian cenderung menurun, termasuk menurunya produksi pertanian pada lahan pertanian dengan radius $500 \mathrm{~m}$ dari pagar yang terpengaruh sorotan lampu pagar area pertambangan. Pendapatan petani pun cenderung menurun karena frekuensi pekerjaan petani sudah berkurang banyak. Akibatnya saat ini petani banyak yang bekerja di luar daerah untuk mencari lahan garapan sebagai akibat berkurangnya lahan garapan yang ada di wilayahnya. Kondisi ini membawa para petani kepada kondisi kerentanan sosial ekonomi sedang, terutama pada petani masih memiliki cukup aset untuk memenuhi kebutuhan perekonomiannya.
\end{abstract}

Kata Kunci : Dampak Perubahan Guna Lahan Pertanian, Sosial Ekonomi Petani.

Abstract: This study examines the impact of agricultural land use change into a petroleum mining area to farmers' socioeconomic conditions around petroleum mining project area in Gayam District of Kabupaten Bojonegoro. The analyses used a mix method, using both quantitative and qualitative approaches. The quantitative approach is used to determine the impact of agricultural land use change on the social and economic aspects with the respondent farmers were supported with a scoring method to determine the condition of socioeconomic vulnerability of farmers, while the qualitative approach carried out through in-depth interviews to some informants who have been affected by the project. The results shows that the presence of the petroleum mining industry has not had a positive impact yet on

\footnotetext{
${ }^{1}$ Badan Perencanaan Pembangunan Daerah (BAPPEDA) Kabupaten Pacitan

2 Departeman Perencanaan Wilayah dan Kota, Fakultas Teknik, Universitas Diponegoro
} 
the farmers' socioeconomic conditions. By the 700 hectares of agricultural land conversion, the agricultural production capacity of the area tends to decrease, including by the decreasing of the productivity of some agricultural land in a radius of $500 \mathrm{~m}$ from the fence of the mining area as they are affected by the fence's spotlight. The farmers' income also tends to decrease because of the decreasing of their working hours as the big loss of agricultural land in the area. As a result, many farmers should work outside of the area to search replacement of the arable land. These situations lead to a moderate condition of social and economic vulnerability for the farmers, especially for those who still have sufficient assets to meet the needs of their economic.

Keywords: Land Use Change Impacts on Agriculture, Farmers' Social Economy.

\section{PENDAHULUAN}

Pertambangan minyak bumi merupakan sumber daya alam yang tidak terbarukan, oleh karenanya harus bijak dalam melakukan kegiatan penambangan. Indonesia merupakan negara yang memiliki banyak potensi sumber daya alam, baik potensi migas maupun non migas. Salah satunya adalah sumber daya alam minyak bumi yang merupakan sumber devisa bagi negara Indonesia. Kabupaten Bojonegoro merupakan kota migas yang memiliki cadangan minyak bumi dan gas dalam jumlah yang besar. Beberapa tahun terakhir aktivitas pertambangan di Kabupaten Bojonegoro meningkat besar, terutama aktivitas pertambangan minyak bumi di Kecamatan Gayam. Tentunya dengan meningkatnya aktivitas pertambangan minyak bumi di Kecamatan Gayam sebanding dengan kebutuhan lahan untuk untuk mendukung aktivitas pertambangan.

Kebutuhan lahan untuk area pertambangan seluas 700 ha, tentu akan menyebabkan terjadinya alih fungsi lahan pertanian di Kecamatan Gayam. Kondisi lahan pertanian Kecamatan Gayam sebagaian besar merupakan lahan pertanian produktif dengan sistem pengairan tadah hujan dan irigasi setengah teknis. Sumber pengairan utama yang dipergunakan untuk mengairi lahan pertanian di Kecamatan Gayam adalah Sungai Bengawan Solo dan sumber air dalam. Terjadinya alih fungsi lahan pertanian akan berpengaruh terhadap kondisi sosial ekonomi petani yang selama ini mengandalkan sektor pertanian sebagai sumber pendapatan utama. Bagi buruh tani, alih fungsi lahan pertanian sangat merugikan karena mata pencaharian buruh tani bergantung pada ketersediaan lahan pertanian di sekitarnya. Alih fungsi lahan pertanian yang terjadi di Kecamatan Gayam menyebabkan sebagian besar buruh tani banyak yang menganggur, sehingga mereka banyak yang menjadi buruh tani sampai di luar kabupaten.

Perekonomian petani masih mengandalkan hasil usaha pertanian sebagai sumber penghidupan utama keluarga, disamping melakukan pekerjaan sampingan lainnya. Selain itu mayoritas petani tidak memiliki pendidikan yang tinggi atau bahkan tidak lulus SD dan tidak memiliki kemampuan di sektor lainnya. Pada aspek perkerjaan di industri pertambangan minyak bumi, tidak semua petani atau anggota keluarga petani bisa menjadi pekerja tambang. Dibutuhkan keahlian khusus di sektor pertambangan minyak bumi dan jenjang pendidikan yang tinggi Kondisi ini tentu akan semakin memperburuk keadaan sosial ekonomi petani dalam rangka pemenuhan kebutuhan perekonomian keluarganya, karena tidak semua petani dapat menyesuaikan diri dengan perubahan tersebut.

\section{METODE PENELITIAN}

Penelitian ini menggunakan metode penelitian survey (kuantitatif) pada sampel yang bersifat homogen dan metode penelitian wawancara (kualitatif) pada responden yang dipilih (purposive). Pengambilan sampel dalam suatu populasi dilakukan secara acak dengan menggunakan teknik simple random sampling/metode pengambilan sampel acak sederhana. Wilayah yang diteliti meliputi desa Sudu, Ngraho, Begadon, Bonorejo, Brabowan, Mojodelik, dan Gayam dengan populasi petani sebanyak 9.716 jiwa. Penetapan populasi didasarkan pada kesamaan sebagai petani (baik petani pemilik lahan, petani 
penggarap, maupun buruh tani), mata pencaharian utama dari pertanian, mengetahui terjadinya proses perubahan penggunaan lahan, dan bertempat tinggal di desa yang menjadi lokasi penelitian. Setelah diketahui jumlah sampel kemudian ditetapkan distribusi sampel dengan menggunakan teknik proportional random sampling berdasarkan unit terkecil desa melalui persamaan:

$$
\frac{\text { jumlah petani padi tiap - tiap desa }}{\text { jumlah total petani padi desa wilayah kajian }} \text { x ukuran sampel ......... persamaan (1) }
$$

Penelitian ini mengkaji pada aspek sosial ekonomi petani yang berkaitan dengan aktivitas sosial ekonomi petani, dampak sosial ekonomi petani, kerentanan sosial ekonomi petani, dan respon sosial ekonomi petani. Analisis kerentanan dilakukan dengan penilaian skoring pada tiap kondisi sosial ekonomi petani yang diperoleh melalui survei primer. Secara rinci penilaian skoring pada untuk tiap indikator kerentanan sosial sosial ekonomi petani dapat dilihat pada Tabel 1.

Tabel 1. Pemberian Skor Indikator Kerentanan Sosial Ekonomi

\begin{tabular}{|c|c|c|c|}
\hline \multirow{3}{*}{$\begin{array}{c}\text { Indikator Kerentanan Sosial } \\
\text { Ekonomi }\end{array}$} & \multicolumn{3}{|c|}{ Kategori Kerentanan Tiap Indikator } \\
\hline & Rendah & Sedang & Tinggi \\
\hline & 1 & 2 & 3 \\
\hline Tingkat pendidikan petani & SMU/Sederajat & SMP/Sederajat & SD/Tidak Lulus SD \\
\hline $\begin{array}{l}\text { Jumlah anggota keluarga } \\
\text { petani }\end{array}$ & 2-3 orang & 4-6 orang & $>6$ orang \\
\hline $\begin{array}{l}\text { Jumlah anak balita dan usia } \\
\text { sekolah }\end{array}$ & 1-2 oramg/tidak ada & 3-4 orang & $>4$ orang \\
\hline $\begin{array}{l}\text { Jumlah anggota keluarga } \\
\text { perempuan }\end{array}$ & 1-2 orang & 3-4 orang & $>4$ orang \\
\hline $\begin{array}{l}\text { Jumlah anggota keluarga } \\
\text { petani berusia lebih dari } 60 \text { thn }\end{array}$ & 1 oramg/tidak ada & $2-3$ orang & $>3$ orang \\
\hline Status kependudukan petani & Asli & $\begin{array}{l}\text { Pendatang (menikah dengan } \\
\text { penduduk desa) }\end{array}$ & \\
\hline Lama tinggal petani & Sebelum tahun 2005 & Antara tahun 2005 s/d 2010 & $\begin{array}{l}\text { Lebih dari tahun } \\
\qquad 2010\end{array}$ \\
\hline $\begin{array}{l}\text { Jumlah pendapatan dari } \\
\text { pertanian }\end{array}$ & > Rp. 2.000.0000,- & $\begin{array}{l}\text { Rp. } 1.000 .000,-\mathrm{s} / \mathrm{d} \\
\text { Rp.2.000.000,- }\end{array}$ & $<$ Rp. $1.000 .000,-$ \\
\hline $\begin{array}{l}\text { Jumlah pendapatan dari } \\
\text { usaha/pekerjaan lainnya }\end{array}$ & > Rp. 1.000.000,- & $\begin{array}{l}\text { Rp. } 500.000,-\mathrm{s} / \mathrm{d} \text { Rp. } \\
1.000 .000,-\end{array}$ & $<$ Rp. 500.000,- \\
\hline $\begin{array}{l}\text { Jumlah pengeluaran keluarga } \\
\text { petani (per bulan) }\end{array}$ & < Rp. 1.000.000,- & $\begin{array}{l}\text { Rp. } 1.000 .000,-\mathrm{s} / \mathrm{d} \\
\quad \text { Rp.2.000.000,- }\end{array}$ & > Rp. 2.000.0000,- \\
\hline Kepemilikan lahan pertanian & Milik Sendiri & Sewa/Gadai & Tidak punya \\
\hline
\end{tabular}

Sumber: Hasil Analisis Peneliti, 2017

Identifikasi nilai skor pada tiap-tiap indikator kerentanan sosial ekonomi didapatkan dari hasil lapangan kemudian dijumlahkan. Ilustrasi perhitungan skor kerentanan sosial ekonomi sebagai berikut:

- Nilai maksimum kerentanan didapatkan dari penjumlahan skor nilai tertinggi kerentanan dengan nilai : $[(3 \times 10=30)+(2 \times 1=2)=32]$

- Nilai minimum kerentanan didapatkan dari penjumlahan skor nilai terendah kerentanan dengan nilai: $(1 \times 11=11)$

Setelah diketahui nilai maksimum dan nilai minimum kerentanan, tahap selanjutnya adalah menentukan klasifikasi kerentanan dengan menggunakan persamaan:

$$
\text { Interval }=\frac{\text { Nilai maksimum }- \text { Nilai minimum }}{\text { Jumlah } \text { klasifikasi }} \ldots \ldots \ldots \text {.....persamaan }(2)
$$


Pengumpulan data dilakukan melalui teknik wawancara, kuisioner, dan observasi. Wawancara dilakukan melalui tatap muka langsung (face to face) dengan dibantu alat perekam. Kuisioner digunakan untuk mendapatkan data dari sampel/responden yang telah ditetapkan. Kuisiober diperlukan untuk mengetahui data yang berkaitan dengan kondisi sosial ekonomi petani, baik dari aktivitas sosial ekonomi petani, dampak sosial ekonomi petani, kerentanan sosial ekonomi petani, dan respon sosial ekonomi petani. Sedangkan observasi dilakukan dengan teknik pengamatan independen (nonpartsipant observation) tanpa terlibat langsung dalam aktivitas petani sehari-hari.

\section{Pertambangan Minyak Bumi di Kecamatan Gayam Bojonegoro}

Pertambangan Banyu Urip berada di Kecamatan Gayam, sekitar $\pm 24 \mathrm{~km}$ dari pusat kota Bojonegoro dan dikelola oleh Mobile Cepu Limited (MCL). Aktivitas pertambangan minyak bumi secara resmi dimulai pada tanggal 17 September 2005, sejak saat itu sektor migas di Kecamatan Gayam berkembang pesat. Meningkatnya aktivitas pertambangan pada dasarnya tidak lepas dari berbagai macam intervensi yang dilakukan oleh pemerintah, baik pusat maupun daerah. Intervensi yang dilakukan oleh pemerintah tidak hanya pada pembangunan infrastruktur tapi juga kemudahan pemberian ijin pertambangan dan aktivitas pendukungnya. Intervensi yang dilakukan oleh pemerintah memberikan pengaruh pada peningkatan aktivitas pertambangan yang berimplikasi pada kebutuhan lahan untuk menunjang aktivitas pertambangan. Kebutuhan lahan untuk mendukung aktivitas pertambangan minyak bumi seluas 700 ha yang disediakan melalui proses ganti rugi lahan pertanian milik masyarakat petani yang tersebar di beberapa desa.

Pertambangan Banyu Urip memiliki 42 sumur yang terdiri dari 29 sumur produksi dan 13 sumur injeksi dan semuanya dikelola oleh ExxonMobile. Sumur Banyu Urip diperkirakan mengandung cadangan minyak bumi lebih dari 250 juta barrel, dengan puncak produksi sekitar 165 ribu barrel minyak per hari (bph). Masuknya industri pertambangan memberikan pengaruh pada perubahan aktivitas di sekitarnya, tidak hanya meningkatnya pembangunan infrastruktur tapi juga mempengaruhi aktivitas pertanian di sekitarnya, yaitu berkurangnya pekerjaan petani sebagai akibat perubahan penggunaan lahan pertanian yang berimbas pada meningkatnya pengangguran di sektor pertanian dan berkurangnya jumlah jam kerja bagi buruh tani. Mayoritas masyarakat di sekitar area pertambangan berprofesi sebagai petani, baik petani pemilik lahan, petani penggarap maupun buruh tani yang menggatungkan hidupnya dari mengolah sumber daya alam yang berupa pertanian.

Perkembangan aktivitas pertambangan Banyu Urip memberikan kontribusi yang besar bagi negara, sekitar 16,5\% menyumbang cadangan minyak nasional pada akhir 2014. Tentunya pertambangan minyak bumi di Kecamatan Gayam memiliki peran sangat penting bagi negara dan bersifat strategis dalam mendukung ketahanan negara di bidang energi dengan tersedianya cadangan minyak bagi negara. Lokasi area pertambangan Banyu Urip terletak di beberapa desa, yaitu Desa Sudu, Ngraho, Bonorejo, Brabowan, Begadon, Mojodelik, Desa Gayam dan menjadi lokasi penelitian seperti terlihat pada Gambar 1. Lokasi penelitian tersebut merupakan desa-desa yang mengalami perubahan lahan pertanian menjadi area pertambangan yang mayoritas mata pencaharian penduduknya adalah petani.

\section{Pengaruh Perubahan Penggunaan Lahan Pertanian Menjadi Pertambangan terhadap Sosial Ekonomi Petani (Literature Review)}

\section{Sosial ekonomi petani}

Sosial ekonomi merupakan bagian dari konsep kesejahteraan, konsep kesejahteraan merupakan suatu kondisi sosial yang sudah tercukupi sandang, pangan, papan, kesehatan, dan pendidikan baik dari segi jasmaniah, rohaniah, maupun sosial (Suharto, 2010). Kesejahteraan sendiri dibedakan menjadi dua pendekatan, yaitu obyektif dan subyektif. Pendekatan obyektif merupakan pendekatan yang berdasarkan pada ukuran-ukuran yang standar dan baku, sedangkan kesejahteraan subyektif mencakup unsur-unsur kognitif seperti kepuasan hidup yang dapat dinilai secara finansial dan komponen afektif seperti kebahagiaan (Milligan et al, 2006). Sesuai dengan konsep kesejahteraan untuk mengetahui 
konsep dasar sosial ekonomi teori yang digunakan adalah kesejahteraan subyektif. Kesejahteraan subyektif merupakan kesejahteraan yang diukur dari perasaan seseorang yang meliputi emosi dan kepuasan seseorang (Ward et al., 2016). Penilian secara subyektif lebih mencerminkan indikator-indikator yang menggambarkan kesejahteraan petani dibanding dengan penilaian secara obyektif.

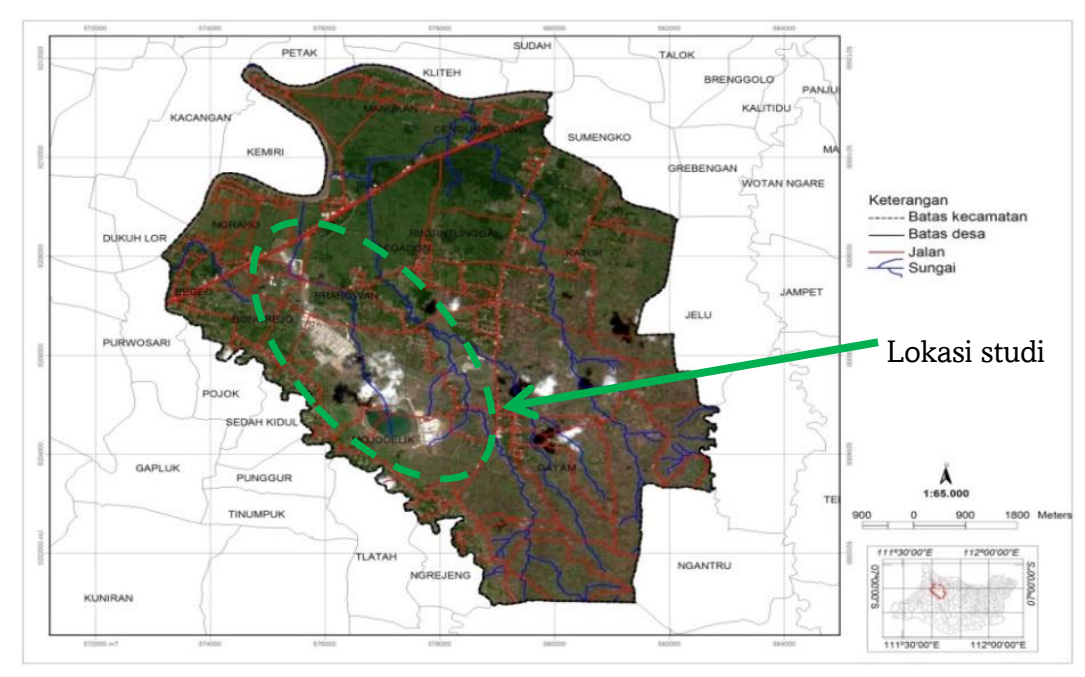

Sumber: Hasil olah data peneliti, 2017

\section{Gambar 1. Peta Lokasi Penelitian}

Merujuk teori di atas, maka konsep sosial ekonomi dapat diartikan sebagai suatu kondisi yang berkaitan dengan aspek sosial ekonomi dalam rangka pemenuhan kebutuhan hidup seperti sandang, pangan, perumahan, pendidikan, dan lain-lain. Sosial ekonomi yang dimaksud merujuk pada ciri khusus yang dimiliki oleh seseorang pada aspek sosial ekonomi dalam upaya pemenuhan penghidupannya. Ciri khusus sosial ekonomi yang dimiliki seseorang berbeda-beda tergatung kekuatan

\section{Dampak Aktivitas Pertambangan Terhadap Sosial Ekonomi Petani}

Dampak menurut Kristanto dalam Sulton (2011) diartikan sebagai adanya suatu benturan antara dua kepentingan yang berbeda, yaitu kepentingan pembangunan dengan kepentingan usaha melestarikan kualitas lingkungan yang baik atau setiap perubahan terjadi dalam lingkungan akibat adanya aktivitas manusia. Dampak yang terjadi tersebut tidak hanya berakibat pada lingkungan saja tapi juga berakibat pada kehidupan manusia di sekitarnya. Dampak yang ditimbulkan dapat bersifat positif maupun negatif tergantung pada obyek yang terkena dampak. Pertambangan umumnya memiliki dampak positif dan negatif pada masyarakat lokal. Perusahaan yang bergerak di bidang pertambangan dapat berkontribusi pada pembangunan infrastruktur sosial ekonomi seperti jalan, rumah sakit, sekolah dan perumahan. Sedangkan pendapatan yang diperoleh dari kegiatan pertambangan memberikan kontribusi positif bagi perekonomian masyarakat, kegiatan pertambangan berfungsi sebagai sumber utama pekerjaan bagi masyarakat lokal, dan memicu pembentukan berbagai usaha kecil seperti jasa katering, transportasi dan kebersihan.

Dampak sosial ekonomi pertambangan merupakan pengaruh kegiatan pertambangan terhadap perubahan sistem sosial petani dalam suatu lingkungan termasuk di dalamnya nilai sosial, sikap, pola perilaku antara kelompok-kelompok dalam masyarakat dan sistem 
perekonomiannya. Menurut Qomariah (2003), keberadaan kegiatan pertambangan yang dilakukan di Kabupaten Banjar-Kalimantan Selatan berpengaruh terhadap aktivitas pertanian, yaitu terjadi penurunan pendapatan dari kegiatan pertanian on farm (usaha tani) yang menunjukkan keberadaan aktivitas pertambangan sangat berpengaruh terhadap menurunnya produktivitas pertanian dan terjadinya kenaikan pendapatan pada kegiatan di luar usaha pertanian (off farm). Tentunya keadaan yang demikian akan mempengaruhi kondisi sosial ekonomi petani di sekitar area pertambangan, terutama petani yang belum terbiasa dengan keberadaan aktivitas pertambangan dan penduduk pendatang yang dapat mempengaruhi sosial ekonomi petani.

\section{Kerentanan Sosial Ekonomi Petani}

Konsep kerentanan sudah diperkenalkan sejak lama, kerentanan pertama kali diperkenalkan oleh Bohle dengan mempernalkan struktur ganda pada kerentanan yang meliputi unsur internal dan eksternal. Kemudian, dikembangkan oleh Turner et al pada penelitian yang dilakukan tahun 2003. Pada tahun 2004, UN/ISDR memandang kerentanan sebagai faktor resiko yang berasal dari dalam (intrinsic vulnerability) yang kemudian dikembangkan lagi oleh Ivanov pada tahun 2005 melalui penelitian kuantitatifnya (Birkmann dan Wisner, 2006).

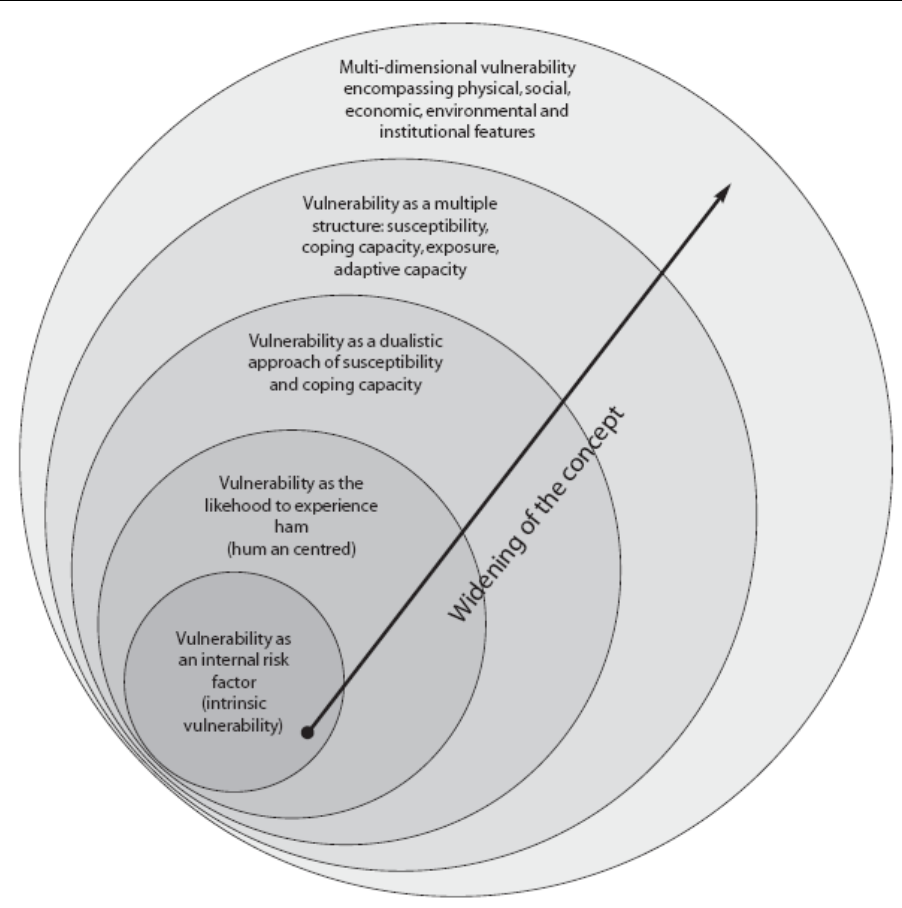

Sumber : Birkmann dan Wisner, 2006

Gambar 2. Perkembangan Konsep Kerentanan

Kerentanan merupakan konsep yang dari ilmu sosial dan diperkenalkan sebagai respon terhadap persepsi suatu resiko yang dapat menimbulkan bencana (Birkmann, 2006). Sedangkan menurut Christiaensen dan Subbarao (2004), kerentanan dapat dipahami sebagai prospek/peluang yang dimiliki seseorang saat ini untuk menjadi miskin di masa mendatang, yaitu peluang menjadi miskin jika saat ini tidak miskin, atau peluang terus menjadi miskin jika saat ini miskin. Kerentanan sering dicirikan sebagai exposure (E), sensitivity (S), dan adaptive capacity (AC), namun faktorfaktor yang mempengaruhinya tergantung subyek yang akan diteliti (Ferrol-schulte et al, 2015). 
Seiring berkembangnya permasalahan dan berjalannya waktu, konsep kerentanan tidak hanya membahas exposure (E), sensitivity (S), dan adaptive capacity (AC), tetapi sudah berkembang pada konsep tematik, yaitu kerentanan fisik/demograpi, sosial, ekonomi, lingkungan, dan isntitusional (Birkmann dan Wisner, 2006). Sehingga dapat dapat dipahami bahwa kerentanan sosial ekonomi petani merupakan kondisi yang terpaparkan sebagai akibat adanya tekanan pada aspek sosial ekonomi yang dapat menimbulkan resiko dalam upaya pemenuhan kebutuhan kehidupannya.

\section{Respon Sosial Ekonomi Petani}

Respon merupakan bentuk ketahanan petani dalam menerima tekanan atau dampak yang diakibatkan dari perubahan penggunaan lahan pertanian menjadi area pertambangan pada aspek sosial ekonomi petani melalui pola adaptasi yang dilakukan oleh petani. Adaptasi merupakan konsep normatif yang terbentuk untuk meningkatkan ketahanan diri (Osbahr, 2007). Ketahanan berhubungan dengan kemampuan untuk beradaptasi dan kemampuan untuk menerima perubahan, ketahanan petani juga bisa dicerminkan melalui respon petani terhadap perubahan yang terjadi. Kerangka utama ketahanan adalah kemampuan untuk beradaptasi dan mengatasi adanya perubahan. Hal ini sesuai dengan Folke yang mendefinisikan ketahanan sebagai kapasitas suatu sistem mengurangi gangguan dan mengorganisir kembali strategi untuk menghadapi perubahan sehingga tetap mempertahankan struktur dasar, identitas dan feedbacks yang diperoleh (Popke et al, 2016).

Fokus penelitian ketahanan petani cenderung menggunakan perspektive sosial yang mencakup beberapa bidang termasuk membahas pembangunan daerah, respon terhadap bencana alam, pembangunan masyarakat, serta respon terhadap kondisi psikologi. Petani sangat bergantung pada kondisi alam dalam mengolah lahan pertaniannya, selain itu juga bergantung pada kondisi perekonomian, politik, dan hubungan sosial kemasyarakatan. Pendekatan yang digunakan adalah dengan melihat proses adaptasi masing-masing petani terhadap tekanan dan perubahan, baik secara sosial, ekonomi, lingkungan, dan faktorfaktor lainnya yang mempengaruhi (Stenbacka et al., 2014).

\section{PEMBAHASAN}

\section{Karakteristik Sosial Ekonomi Petani}

Karakteristik sosial ekonomi petani merupakan ciri khusus yang mencerminkan kondisi petani dalam rangka pemenuhan kebutuhan hidupnya dan keluarga. Karakteristik sosial ekonomi dapat dilihat dari berbagai sudut pandang tergantung kebutuhan penelitian dan sararan yang akan diteliti. Pada penelitian ini karakteristik sosial ekonomi petani yang diteliti meliputi umur, jenis kelamin, tingkat pendidikan, pendapatan, dan kepemilikan lahan pertanian.

\section{Karakteristik Umur Petani}

Umur merupakan salah satu karakteristik individu yang sangat berperan dalam menentukan kemampuan kerja dan produktifitas kerja (Awang et al, 2012). Hasil penelitian menunjukkan bahwa usia petani di sekitar area pertambangan tergolong masih produktif, meskipun ada beberapa yang petani yang memiliki usia diatas 65 tahun namun bukan menjadi penghalang untuk melakukan rutinitas sebagai petani. Dari segi kategori umur, petani yang memiliki usia 46 tahun ke atas sebanyak 61 orang responden $(61,62 \%)$, sedangkan petani yang memiliki usia antara $15 \mathrm{~s} / \mathrm{d} 25$ tahun hanya 1 orang responden saja $(1,01 \%)$, dan sisanya merupakan petani yang memiliki usia antara $26 \mathrm{~s} / \mathrm{d} 45$ tahun $(37,37 \%)$ 
Hal ini menunjukkan bahwa kurangnya minat masyarakat petani yang memiliki usia dibawah 25 tahun pada sektor pertanian yang disebabkan sektor pertanian bukanlah pekerjaan yang favorit, belum bisa dijadikan sebagai pekerjaan tetap, dan belum bisa menjanjikan karena penghasilannya tidak pasti. Mereka lebih memilih bekerja sebagai buruh pada perusahaan atau sebagai pekerja di sektor riil lainnya yang memiliki penghasilan tetap setiap bulannya. Petani yang memiliki usia diatas 35 tahun lebih sabar dan dewasa dalam mengolah lahan pertanian meskipun dari segi fisik/kekuatan mengalami penurunan.

\section{Karakteristik Jenis Kelamin}

Jenis kelamin merupakan perbedaan sifat, bentuk dan fungsi biologi antara laki-laki dan perempuan. Hasil penelitian menunjukkan bahwa, sebanyak 68 responden (68,69\%) merupakan petani laki-laki dan sebanyak 31 responden $(31,31 \%)$ merupakan petani perempuan.

Hal ini menunjukkan bahwa, dalam pengelolaan sumber daya alam pertanian di sekitar area pertambangan sudah melibatkan peran gender dan tidak menganggap pekerjaaan petani hanya milik kaum laki-laki saja, walaupun bertani merupakan jenis pekerjaan kasar dan berat bagi kaum perempuan. Hal ini membuktikan bahwa pelibatan peran gender di sekitar area pertambangan sangat baik dan tidak terjadi diskriminasi pada kaum perempuan.

\section{Karakteristik Tingkat Pendidikan Petani}

Tingkat pendidikan dapat mempengaruhi cara berpikir seseorang, terutama dalam menganalisis suatu permasalahan yang dihadapi. Semakin tinggi tingkat pendidikan maka tingkat pengetahuannya juga akan semakin baik (Awang et al, 2012). Hasil penelitian menunjukkan tingkat pendidikan petani di sekitar area pertambangan masih tergolong rendah yaitu hanya lulus SD atau bahkan tidak lulus SD $(81,82 \%)$. Kondisi yang demikian tentu akan berdampak pada pembentukan karakter dan pola pikir petani yang tentunya akan mempengaruhi lambatnya proses alih informasi pada petani.

Tingkat pendidikan sangat penting pada kegiatan pertanian terutama dalam transfer pengetahuan pertanian dan pengolahan hasil pertanian yang baik. Semakin tinggi tingkat pendidikan akan semakin mudah dalam menerima teknologi baru pada sektor pertanian. Tingkat pendidikan petani yang rendah akan sulit untuk menerima perubahan secara cepat dan dibutuhkan proses yang lama untuk memberikan pemahaman kepada petani.

\section{Karakteristik Pendapatan Petani}

Pendapatan merupakan salah satu indikator untuk mengukur kesejahteraan petani. Tingkat pendapatan petani sebelum ada industri pertambangan dengan sesudah adanya industri pertambangan bila dibandingkan tidak jauh berbeda yang seharusnya pendapatannya lebih tinggi. Rata-rata pendapatan petani berada dikisaran antara Rp. 1.000.000,- s/d Rp. 2.000.000,- perbulan. Berdasarkan hasil penelitian menunjukkan bahwa sebelum ada industri pertambangan, $66,67 \%$ petani memiliki pendapatan sebulan antara Rp. 1.000.000,- s/d Rp. 2.000.000,- sedangkan yang memiliki yang memiliki pendapatan di atas Rp. 2.000.000,- hanya $22,22 \%$. Sedangkan setelah ada industri pertambangan pada ring pendapatan yang sama antara 1.000.000,- s/d Rp. 2.000.000,- menurun yaitu sebanyak $61,62 \%$, sedangkan petani yang memiliki pendapatan di atas Rp. 2.000.000,- meningkat menjadi $25,25 \%$.

Rata-rata pendapatan petani per bulan cenderung tidak berubah dibanding dengan sebelum ada industri pertambangan. Meskipun pendapatan petani termasuk rendah, 
mereka mampu bertahan walaupun ada perubahan yang mengharuskan petani berpikir keras untuk memperoleh pengahsilan tiap bulannya. Sebagaimana telah ditetapkan oleh BPS (2016) kebutuhan minimum layak di di daerah Propinsi Jawa Timur adalah sebesar Rp. 825.000,- perbulan. Jika petani memiliki pendapatan diatas Rp. 1.000.000,- maka mereka masih mampu bertahan hidup walaupun agak berat untuk mencukupi semua kebutuhan.

\section{Karakteristik Kepemilikan Lahan Pertanian}

Kepemilikan lahan pertanian sangat penting dalam menunjang aktivitas petani, karena lahan pertanian sangat berhubungan dengan pendapatan petani dan identik dengan kesejahteraan petani. Berdasarkan hasil penelitian, sebanyak 77,78\% petani memiliki lahan pertanian hak milik, sisanya merupakan lahan sewa dan tidak punya lahan pertanian, masing-masing $11,11 \%$. Dari $88,89 \%$ petani yang memiliki lahan pertanian kurang dari 0,5 ha yaitu sebanyak $61,62 \%$, sisanya memiliki lahan antara $0,5-1$ ha $(16,16 \%)$, dan di atas 1 ha $(11,11 \%)$.

Kepemilikan lahan pertanian merupakan salah satu faktor yang menentukan pendapatan petani, karena pendapatan petani bergantung pada ketersediaan lahan pertanian. Semakin luas lahan pertanian maka semakin besar tingkat pendapatan yang diterima petani dari hasil pertanian. Lahan pertanian juga sangat penting bagi petani untuk mempertahankan hidup dan juga merupakan tabungan bagi petani walaupun lahan pertanian yang dimiliki tidak luas.

\section{Aktivitas Sosial Ekonomi Petani}

Aktivitas sosial ekonomi petani merupakan gambaran secara umum aktivitas petani di sekitar area pertambangan, mayoritas petani berprofesi sebagai petani pemilik lahan dan buruh tani. Setelah adanya aktivitas pertambangan, roda perekonomian petani tetap mengandalkan pertanian sebagai mata pencaharian utama. Pertumbuhan ekonomi yang tinggi tidak selalu mencerminkan meratanya distribusi pendapatan/peningkatan kesejahteraan secara adil dan merata. Kondisi tersebut dapat dilihat dari tingkat kesejahteraan petani di sekitar area pertambangan, petani masih tergolong miskin meskipun belum ada angka pasti yang menyebut tingkat kemiskinan petani di sekitar area pertambangan.

Adanya industri pertambangan belum memberikan perubahan yang signifikan pada peningkatan perekonomian petani, terutama buruh tani. Bagi buruh tani perubahan penggunaan lahan pertanian berarti berkurangnya pendapatan. Petani yang hanya bekerja sebagai buruh tani saja sangat mengandalkan pendapatan dari pekerjaan sebagai buruh tani, berbeda dengan buruh tani yang juga sebagai petani pemilik lahan. Mereka masih bisa berharap hasil produksi pertanian dari lahan yang dimiliki dan tetap mengharapkan pendapatan dari buruh tani.

Aktivitas pertanian mengalami perubahan, jumlah hari kerja buruh tani mengalami penurunan secara signifikan. Buruh tani lebih banyak menganggur daripada bekerja, hal ini disebabkan lahan pertanian di sekitar desanya atau desa-desa terdekat banyak yang beralih fungsi. Untuk memenuhi kebutuhan ekonomi keluarganya, ada sebagian buruh tani yang mulai mencari tambahan penghasilan sampai ke luar wilayah kabupaten. Pekerjaan yang dilakukan pun sama, yaitu sebagai buruh tani.

\section{Hubungan Sosial Petani}

Hubungan sosial sangat penting dalam membangun jaringan sosial yang menjadi dasar dalam membangun ketahanan petani. Berdasarkan hasil penelitian menunjukkan bahwa semua responden memiliki hubungan sosial yang kuat diantara petani lainnya dan 
dengan masyarakat di sekitarnya. Hubungan sosial diantara petani terbentuk secara tidak sengaja tanpa ada campur tangan dari pihak lain. Pola hubungan sosial tersebut dilandasi hubungan kemasyarakatan dan pola hubungan kerja yang saling membutuhkan. Petani pemilik lahan dan buruh tani membentuk hubungan sosial yang dinamis, satu dengan yang lainnya.

Kedinamisan hubungan sosial diantara petani memberi manfaat yang besar bagi petani untuk meningkatkan kesejahteraan keluarga dalam rangka pemenuhan kebutuhan ekonomi keluarganya. Dalam hubungan sosial, petani memiliki rasa saling percaya antara satu dengan lainnya yang berlandaskan norma yang ada dan saling menghargai. Hubungan sosial yang terbentuk diantara petani memiliki ikatan yang kuat, jika petani merasakan susah maka petani lainnya akan berusaha memberikan solusi agar bisa keluar dari kesusahan yang dialami petani.

\section{Dampak Terhadap Sosial Ekonomi Petani}

\section{Dampak Terhadap Ketrampilan Petani dan Pendidikan Keluarga Petani}

Meningkatnya aktivitas pembangunan suatu wilayah ternyata tidak meningkatkan keahlian petani di sektor lainnya, terutama keahlian yang berkaitan dengan industri pertambangan. Keahlian yang dimiliki petani hanya berdasarkan pengalaman yang dimiliki dan tidak bersertifikat. Petani cenderung enggan untuk mencari pendidikan non formal karena tidak difasilitasi dan tidak ada biaya jika harus mencari sendiri.

Meningkatnya aktivitas pertambangan ternyata belum bisa menjadi pendorong untuk menempuh pendidikan formal, melalui penyediaan sarana prsarana pendidikan. Berdasarkan hasil penelitian menyatakan bahwa keberadaaan industri pertambangan minyak Bumi di Kecamatan Gayam tidak berdampak pada peningkatan pendidikan keluarga secara langsung. Kesadaran keluarga petani untuk memberikan pendidikan sudah ada sebelum ada indutri pertambangan. Tumbuhnya kesadaran tersebut dipicu karena kebutuhan akan pendidikan yang lebih baik dan bisa digunakan untuk mencari pekerjaan di sektor lainnya.

\section{Dampak Terhadap Migrasi Masuk dan Konflik Sosial}

Masuknya industri pertambangan minyak bumi tentu akan berpengaruh pada pergerakan penduduk dari luar wilayah, terutama memicu terjadinya migrasi penduduk. Berdasarkan hasil penelitian menunjukkan bahwa keberadaan industri pertambangan menyebabkan terjadinya migrasi masuk ke desa-desa yang dekat dengan area pertambangan. Kebanyakan penduduk yang masuk merupakan tenaga skill yang dibutuhkan oleh perusahaan.

Keberadaan penduduk pendatang tidak berdampak pada terjadinya konflik sosial, namun keberadaan penduduk pendatang memicu terjadinya kecemburuan sosial tetapi tidak sampai menimbulkan terjadinya konflik sosial. Kecemburuan sosial yang terjadi berkaitan dengan peluang kerja pada industri pertambangan. Petani berharap dengan adanya industri pertambangan dapat memberi peluang kerja pada industri pertambangan, walaupun kenyatannya sangat sulit karena terbentur dengan tingkat pendidikan dan keahlian yang dimiliki petani rendah. Rata-rata petani yang bisa menjadi pekerja tambang hanya sebagai pekerja kasar dan bersifat sementara berdasarkan kontrak kerja.

Keberadaan industri pertambangan juga berdampak pada berkurangnya hasil produksi pertanian terutama lahan pertanian yang berada di dekat pagar area pertambangan. Berdasarkan hasil pengamatan, adanya lampu di pinggir pagar milik perusahaan tambang menyebabkan berkurangnya hasil produksi pertanian dengan radius lahan pertanian sampai 500m dari pagar. Adanya sorotan lampu menyebabkan tanaman 
padi telat buahnya dan jagung tidak mau berbuah, atau tanaman pertanian lain yang buahnya diatas tanah. Hal ini tidak sampai menimbulkan terjadinya konflik dengan perusahaan tambang, petani sudah menyampaikan kejadian tersebut pada pihak Pemerintah Desa yang kemudian diteruskan kepada pihak perusahaan dan Pemerintah Kabupaten. Berdasarkan laporan tersebut, pihak perusahaan sudah melakukan tindakan dengan merubah arah sorotan lampu masuk ke dalam area perusahaan tetapi belum semua lampu dirubah arahnya, masih ada beberapa lampu yang masih mengarah ke lahan pertanian. Sedangkan dari pihak kabupaten sudah bertindak dengan melakukan uji lapangan dan sampai sekarang sudah lebih dari satu tahun hasilnya belum dipublikasikan dengan alasan menunggu hasil laborat dari Jakarta sehingga penyebab pasti berkurangnya produksi pertanian belum diketahui secara pasti.

Konflik sosial yang pernah terjadi di sekitar area pertambangan berkaitan dengan keluarnya gas flare yang berakibat pada kesehatan penduduk di sekitar area pertambangan terutama di Desa Mojodelik dan Gayam. Konflik tersebut dilakukan dalam bentuk demo yang menuntut kompensasi pada perusahaan pertambangan yang dilakukan oleh beberapa petani dari Desa Mojodelik (7,07\%). Konflik sosial yang berkaitan dengan petani di sekitar area pertambangan tidak sampai menimbulkan persamasalahan serius. Pihak Pemerintah Desa tanggap dalam mengantisipasi dan menangani permasalahan yang muncul akibat aktivitas pertambangan terhadap petani serta pihak perusahaan mau mendengarkan dan masih peduli terhadap lingkungan di sekitarnya.

\section{Dampak Terhadap Pekerjaan di Sektor Pertanian}

Masuknya industri pertambangan belum memberikan pengaruh positif secara langsung pada petani di sekitarnya. Hanya ada beberapa petani yang dapat merasakan manfaat keberadaan industri pertambangan walaupun bersifat sementara. Berdasarkan hasil penelitian, sebanyak $47,47 \%$ petani menyatakan keberadaan industri pertambangan mempengaruhi pekerjaan di sektor pertanian. Sedangkan 52,53\% petani menyatakan keberadaan industri pertambangan tidak berpengaruh pada pekerjaan di sektor pertanian.

Pesatnya aktivitas pertambangan di Kecamatan Gayam sangat mempengaruhi pekerjaan pada sektor pertanian. Kondisi ini sangat dirasakan terutama petani yang berprofesi sebagai buruh tani yang selama ini mengandalkan lahan pertanian milik petani lainnya. Berkurangnya lahan pertanian ternyata mempengaruhi jumlah hari kerja buruh tani di sekitar area pertambangan dan meningkatnya pengangguran sebagai akibat berkurangnya lahan pertanian.

\section{Dampak Terhadap Tingkat Pendapatan Petani}

Terjadinya perubahan penggunaan lahan pertanian di beberapa desa ternyata memberikan pengaruh pada pendapatan yang diperoleh petani. Berdasarkan hasil penelitian memperlihatkan bahwa sebanyak 32,32\% petani menyatakan keberadaan industri pertambangan tidak berpengaruh pada pendapatan petani, sebanyak 64,64\% petani menyatakan keberadaan industri pertambangan berpengaruh terhadap pengurangan penghasilan, dan hanya 3,03\% petani yang menyatakan keberadaan industri pertambangan justru menguntungkan atau menambah penghasilan.

Pendapatan petani memang sangat bergantung pada hasil pertanian, adanya industri pertambangan bisa menjadi alternatif untuk mendapatkan tambahan penghasilan namun kenyataannya sulit untuk mewujudkan hal tersebut. Pendapatan petani di sekitar area pertambangan tidak mengalami peningkatan dan tergolong masih rendah untuk ukuran umumnya, sehingga perlu diwaspadai bahwa jangan sampai kondisi petani nantinya lebih buruk dibanding saat ini. 


\section{Dampak Terhadap Peluang Usaha Bagi Petani}

Keberadaan industri pertambangan minyak bumi di Kecamatan Gayam belum berpengaruh terhadap petani untuk mendirikan usaha. Kebanyakan petani belum memiliki keinginan untuk membuka usaha seperti warung atau toko. Berdasarkan hasil penelitian hanya 5,05\% petani yang dapat memanfaatkan keberadaan industri pertambangan dengan membuka usaha warung makan yang pada saat terjadinya migrasi masuk. Pertambahan penduduk di sekitar area pertambangan ternyata belum bisa dimanfaatkan oleh petani secara maksimal, petani cenderung monoton dan merasa sudah nyaman dengan pendapatan sekarang walaupun pendapatannya belum bisa dipastikan setiap bulannya.

\section{Kerentanan Sosial Ekonomi Petani}

Terjadinya perubahan pengguanaan lahan merupakan sebuah tekanan bagi petani yang dapat menyebabkan terjadinya kerentanan pada aspek sosial ekonomi. Analisis kerentanan sosial ekonomi petani dilakukan melalui survei pada tingkatan skala lokal (rumah tangga) petani di sekitar area pertambangan. Indikator yang telah ditetapkan dijadikan dasar dalam penilaian kerentanan, masing-masing indikator memberikan pengaruh yang berbeda-beda tergantung aset penghidupan yang dimiliki oleh petani. Kondisi kerentanan petani diperoleh dengan menjumlahkan nilai pada masing-masing baris indikator kerentanan yang telah ditetapkan. Hasilnya dibagi dalam empat kelas, seperti terlihat pada Tabel 2 dibawah.

Tabel 2. Kondisi Kerentanan Sosial Ekonomi Petani di Sekitar Area Pertambangan

\begin{tabular}{lllcc}
\hline No & Nilai Kerentanan & Kondisi Kerentanan & Jumlah Responden & Prosentase \\
\hline 1 & $11,00-16,25$ & Rendah & 18 & $18,18 \%$ \\
2 & $16,26-21,51$ & Sedang & 79 & $79,80 \%$ \\
3 & $21,52-26,77$ & Tinggi & 2 & $2,02 \%$ \\
4 & $26,78-32,00$ & Sangat Tinggi & 0 & 0 \\
\hline \multicolumn{5}{l}{ Sumber: Hasil Analisis Peneliti, 2017}
\end{tabular}

Berdasarkan hasil penelitian, mayoritas petani dengan berada pada kondisi kerentanan sedang $(79,80 \%)$, yang berarti bahwa petani masih memiliki aset penghidupan yang cukup untuk memenuhi kebutuhan perekonomiannya meskipun terjadi tekanan akibat perubahan penggunaan lahan. Kondisi kerentanan tersebut lebih dipengaruhi oleh indikator tingkat pendidikan petani, jumlah anggota keluarga petani, jumlah pendapatan dari pertanian, jumlah pendapatan dari usaha/pekerjaan lainnya, jumlah pengeluaran keluarga petani (per bulan).

\section{Respon pada Aspek Sosial Ekonomi Petani}

Respon merupakan tindakan untuk mengurangi tekanan/gangguan sebagai akibat berubahnya kondisi lingkungan di sekitarnya. Respon petani digambarkan sebagai bentuk adaptasi petani untuk meningkatkan ketahanan petani melalui tindakan/strategi yang dilakukan untuk mengurangi tingkat kerentanan petani akibat perubahan penggunaan lahan pertanian. Berdasarkan hasil penelitian, strategi adaptasi yang paling banyak dipilih petani adalah memanfaatkan hubungan sosial atau jaringan sosial (100\%). Hal ini menunjukkan bahwa hubungan sosial sangat penting bagi petani dalam membangun kebertahanan diri dan merupakan ikatan yang paling kuat karena memiliki unsur kepercayaan antar petani.

Masing-masing petani memiliki strategi/upaya yang berbeda-beda untuk mengurangi kerentanan, tergantung pada kekuatan penghidupan masing-masing petani. Strategi adaptasi yang paling dominan bisa diartikan sebagai strategi yang paling 
mencerminkan kebertahanan petani dalam menghadapi perubahan penggunaan lahan pertanian.

\section{Tanggung Jawab Perusahaan Tambang}

Tanggung jawab perusahaan yang diberikan oleh perusahaan tambang merupakan cerminan kepedulian perusahaan tambang. Namun kepedulian perusahaan tambang belum bisa menyelesaikan masalah yang terjadi di sekitar area pertambangan, terutama masalah yang berkaitan dengan kondisi sosial ekonomi petani. Tanggung jawab perusahaan selama ini diberikan dalam bentuk CSR dan kompensasi. CSR dari perusahaan tambang diberikan dalam bentuk bantuan keuangan yang masuk dalam program desa untuk membantu pembiayaan pembangunan desa dan lebih banyak diarahkan pada pembangunan infrastruktur desa.

Sedangkan kompensasi dari perusahaan tambang berupa bantuan beras yang diperuntukan bagi petani yang terkena dampak akibat aktivitas pertambangan dan lebih bersifat situasional. Aktivitas perusahaan tambang baru-baru ini yang berdampak pada penduduk yaitu berkaitan dengan keluarnya gas flare yang berpengaruh pada kesehatan penduduk di Desa Mojodelik dan Gayam. Berdasarkan hasil penelitian, penduduk di Desa Mojodelik dan Gayam mendapatkan kompensasi berupa beras yang jumlahnya berbedabeda tergantung jauh dekatnya rumah dari sumber gas flare.

CSR maupun kompensasi yang telah diberikan oleh perusahaan tambang belum bisa meningkatkan kesejahteraan petani dan menyelesaikan masalah yang terjadi, seharusnya CSR bisa diarahkan pada pembangunan lainnya yang terintegrasi dengan aktivitas petani di sekitar area pertambangan, seperti perbaikan kapasitas pertanian dan perbaikan kapasitas petani selain infrastruktur pedesaan. Perbaikan pada ketiga aspek di atas mengandung makna bahwa kesejahteraan petani meningkat, dimana titik tekannya adalah kelangsungan hidup petani sehingga dapat meningkatkan adaptasi petani akibat adanya tekanan yang dirasakan langsung oleh petani.

\section{Tantangan Peningkatan Manfaat Berkembangnya Aktivitas Pertambangan Banyu Urip Bagi Petani}

Perkembangan aktivitas pertambangan Banyu Urip memunculkan dua persoalan pokok dan berkaitan erat dengan aktivitas petani di sekitarnya. Dua persoalan tersebut antara lain, meningkatnya pengangguran di sektor pertanian sebagai akibat berkurangnya lahan pertanian yang berpengaruh pada ketersediaan lapangan kerja pada sektor pertanian; dan berkurangnya jumlah jam kerja bagi buruh tani sebagai akibat perubahan penggunaan lahan pertanian yang berpengaruh pada berkurangnya luasan lahan pertanian,

Persoalan di atas merupakan persoalan yang muncul di sekitar area pertambangan yang harusnya mendapat perhatian serius dari Pemerintah Daerah dan perusahaan tambang. Keberadaan industri pertambangan yang seharusnya memberikan harapan bagi peningkatan kesejahteraan petani ternyata belum memberikan manfaat lebih pada penghidupan petani di sekitarnya. Persoalan yang muncul tersebut berkaitan dengan aktivitas sosial ekonomi petani seiring berkembangnya aktivitas pertambangan Banyu Urip, yang tentunya memberikan tantangan bagi Pemerintah Daerah untuk memberikan manfaat lebih melalui program yang menyentuh langsung petani dengan tujuan untuk: (1) mengembalikan produktivitas pertanian pedesaan sebagai akibat berkurangnya lahan pertanian yang diokupasi menjadi pertambangan minyak bumi melalui perbaikan irigasi pertanian yang terintegrasi mulai dari hulu sampai ke hilir sehingga dapat menunjang aktivitas pertanian di sekitar area pertambangan dan meningkatkan produksi pertanian melalui penerapan teknologi pertanian yang mudah diterapkan; (2) menciptakan lapangan 
kerja akibat berkurangnya jam kerja petani dengan mendirikan industri pertanian untuk mengolah hasil pertanian yang tentunya akan membutuhkan tenaga kerja banyak.

Tujuan diatas dapat diwujudkan dengan kerjasama antara Pemerintah Daerah dan pihak perusahaan tambang untuk mereduksi persoalan yang muncul melalui program CSR sebagai pengganti berubahnya lahan pertanian yang berpengaruh pada produktivitas pertanian sehingga dapat meningkatkan kesejahteraan petani. Konsep yang digunakan adalah pengembangan industri pertanian dengan mengintegrasikan antara aktivitas pertambangan dan aktivitas pertanian sehingga saling mendukung.

Industri pertanian yang dimaksud merupakan sebuah area industri pengolahan hasil pertanian ramah lingkungan yang terdiri dari unit pengolahan hasil pertanian dan gudang pertanian untuk menyimpan hasil pertanian yang sudah diolah. Pengembangan industri pertanian tersebut dapat memanfaatkan keberadaan industri pertambangan untuk mengolah hasil pertanian, yaitu dengan memanfaatkan gas flare yang tidak terpakai oleh industri pertambangan sebagai panas buatan untuk pengeringan padi yang disalurkan melalui blower pada unit pengolahan hasil pertanian. Keberadaan industri pertanian tersebut tentunya harus didukung dengan sarana infrastruktur yang memadai yaitu jalan yang memadai untuk aksesibilitas transportasi dan kedekatan dengan gas flare. Kriteria wilayah yang sesuai dengan dua hal tersebut hanya Desa Gayam yang cocok untuk dikembangkan sebagai wilayah untuk pengembangan industri pertanian. Pengembangan industri pertanian di Desa Gayam diharapkan dapat memberi harapan yang positif bagi petani sehingga dapat mereduksi persoalan yang muncul berkaitan dengan aktivitas pertanian di sekitar area pertambangan. Industri pertanian tersebut juga dapat memberikan nilai lebih bagi pengembangan wilayah Desa Gayam, sehingga Desa Gayam dapat menjadi pusat pengolahan hasil pertanian yang pertama di Kabupaten Bojonegoro dengan memanfaatkan gas flare yang melayani tidak hanya wilayah Kecamatan Gayam saja tapi juga wilayah-wilayah di sekitarnya, sehingga produksi pertanian di Kabupaten Bojonegoro dapat meninggkat. Selain itu, juga dapat dikembangkan pembangunan kawasan permukiman yang disediakan bagi karyawan industri pertambangan atau masyarakat sekitarnya, sehingga aktivitas perekonomian berkembang di wilayah tersebut yang dapat menjadi pendorong pengembangan wilayah perkotaan di Desa Gayam yang berbasis industri pertanian dan industri pertambangan.

\section{KESIMPULAN}

Aktivitas pertanian di sekitar area pertambangan mengalami perubahan dengan berkurangnya luas lahan pertanian secara signifikan. Perubahan tidak hanya terjadi pada berkurangnya kapasitas produksi pertanian pasca perubahan lahan yang terjadi, tetapi juga berkurangnya jam atau hari kerja yang tersedia bagi para petani, terutama buruh tani. Adanya perubahan penggunaan lahan pertanian justru menambah pengangguran di sektor pertanian, terutama buruh tani. Rendahnya tingkat pendidikan dan terbatasnya ketrampilan petani menyebabkan banyak petani (buruh tani) harus mencari lahan garapan sampai ke luar wilayahnya, bahkan hingga di Kabupaten Lamongan untuk mendapatkan cash income setiap harinya. Tingkat kesejahteraan petani pun belum mengalami peningkatan, sebagai akibatnya tingkat kesejahteraan petani belum mengalami peningkatan.

Keberadaan industri pertambangan di Kecamatan Gayam belum memberikan dampak positif pada kesejahteraan petani di sekitar area pertambangan. Kesempatan bekerja di sektor pertambangan bagi petani sangatlah kecil. Hanya sedikit petani atau anggota keluarga petani yang bisa masuk menjadi pekerja di proyek pertambangan meskipun hanya sebagai tenaga kerja kasar dan bersifat sementara. Harapanya dengan adanya industri pertambangan, ada lowongan pekerjaan untuk petani di sekitar area pertambangan, namun harapannya tidak sesuai dengan kenyataan yang ada saat ini karena 
terbentur dengan tingkat pendidikan petani yang rendah atau keahlian yang dimiliki petani terbatas.

Kepedulian perusahaan yang berupa CSR dan kompensasi selama ini belum menyentuh langsung pada sektor pertanian yang terkena dampak langsung. Program CSR tentunya dapat diarahkan pada upaya perbaikan kapasitas pertanian melalui pengembangan industri pertanian dan perbaikan kapasitas petani untuk mendukung industri pertanian serta perbaikan infrastruktur pertanian, sehingga persoalan muncul berkaitan dengan aktivitas pertanian di sekitar area pertambangan dapat dikurangi. Harapannya dengan berkembangnya industri pertambangan, aktivitas pertanian juga meningkat walaupun lahan pertaniannya berkurang banyak sehingga keberadaan industri pertambangan dapat memberikan pengaruh yang positif bagi petani.

\section{DAFTAR PUSTAKA}

Awang, S.A. et al. 2016. An Assessment of The Socio-economic Impact of Maiganga Resettlement Scheme, Akko LGA, Gombe State Nigeria. International Journal of Environmental \& Agriculture Research (IJOEAR). Vol. 2. pp 101-109.

Birkmann, J. 2006. Measuring Vulnerability To Natural Hazards. United Nation University Press. New York, Amerika Serikat.

Birkmnan, J. dan Ben Wisner. 2006. Measuring The Un-Measurable. The Challenge of Vulnerability. United Nation University. Bornheim, German.

Birkmann, J. 2007. Risk and Vulnerability Indicators at Different Scales, Applicability, Usefulness and Policy Implications. Environmental Hazard. pp 20-31.

Christiaensen dan Subbarao. 2004. Toward an Understanding of Household Vulnerability in Rural Kenya. World Bank Policy Research Working Paper. http://econ.worldbank.org

Christiaensen dan Subbarao. 2004. Toward an Understanding of Household Vulnerability in Rural Kenya. World Bank Policy Research Working Paper 3326. pp 1-44.

Creswell, J.W. 2010. Research Design: Pendekatan Kualitatif, Kuantitaif dan Mixed. Yogyakarta: Pustaka Pelajar.

Ferrol-Schulte, D. et al. 2015. Coastal Livelihood Vulnerability to Marine Resource Degradation: A Review of the Indonesian National Coastal and Marine Policy Framework. Marine Policy. pp 163-171.

Milligan, S. et al. 2006. Family Wellbeing Indicators From The 1981 - 2001 New Zealand Censuses. New Zealand: Statistics New Zealand.

Osbahr, H. 2007. Building Resilience: Adaptation Mechanisms and Mainstreaming for the Poor. UNDP Human Development Report. Pp 1-38.

Popke, J. et al. 2016. A Social Justice Framing of Climate Change discourse and Policy: Adaptation, Resilience and Vulnerability in a Jamaican Agricultural Landscape. Geoforum. pp 70-80.

Qasim, S. et al. 2016. Community Resilence to Flood Hazard in Khyber Pukhthunkhwa Province of Pakistan. International Journal of Disaster Risk Reduction. pp 100-106.

Qomariah, R. 2003. Dampak Kegiatan Pertambangan Tanpa Ijin (PETI) Batubara Terhadap Kualitas Sumberdaya Lahan dan Sosial Ekonomi Masyarakat di Kabupaten Banjar-Kalimantan Selatan. Tesis tidak diterbitkan, Program Pascasarjana Institut Pertanian Bogor, Bogor.

Stenbacka, Susanne et al. 2014. Balancing Family Traditions and Business: Gendered Strategies For Achieving Future Resilence Among Agriculural Students. Journal of Rural Studies. pp 152-161.

Sugiyono, Adam. 2015. Metode Penelitian Kuantitatif, Kualitatif, dan R\&D. Cetakan ke-22. Alfabeta. Bandung

Sulton, A. 2011. Dampak Aktivitas Pertambangan Bahan Galian Golongan C Terhadap Kondisi Kehidupan Masyarakat Desa. Skripsi tidak diterbitkan, Departemen Sains Komunikasi dan Pengembangan Masyarakat Fakultas Ekologi Manusia Institut Pertanian Bogor, Bogor.

Ward, J. et al. 2016. Exploring The Relationship Between Subjective Wellbeing and Groundwater Attitudes and Practices of Famers in Rural India. Journal of Hydrology. pp 1-16. 